\title{
The Importance of Second-Hand Knowledge in the Revised Uppsala Model: Can European Textiles Producers Export to China?
}

\author{
Susana Costa e Silva \\ Eugénia Pacheco \\ Raquel Meneses \\ Carlos Brito
}

\begin{abstract}
The authors studied how knowledge derived from firms' relationships-the so-called second-hand knowledge-is likely to influence their internationalization process. In this article, they examine how a European producer of textiles is able to sell worldwide, including to China, a highly competitive player in this industry. This article discusses models of firms' networks and the extent to which such networks generate important knowledge that can explain internationalization behavior-how it is able to influence the selection of foreign markets and the entry mode used. The authors use the revised version of the Uppsala model of internationalization, which emphasizes the roles of trust-building, knowledge, and creation of opportunities within relationships.
\end{abstract}

KEYWORDS. Internationalization, knowledge, relationship, Uppsala model

\section{INTRODUCTION}

International business literature lacks new explanations for internationalization that are more consentaneous with the new business milieu. A specific interest emerged in studying and understanding how companies establish relationships and how these relations can influence their internationalization processes (Christensen \& Lindmark, 1993; Kaufmann, 1994; O'Farrell \& Hitchens, 1988). These relationships generate knowledge that is believed to be crucial in the firm's future internationalization decisions.
This is even more significant in the case of small and medium-sized enterprises with limited resources that, according to Rochester (2005), has to do with the "liability of smallness." In this context, business relationships gained relevance and therefore new explanations are demanded. One attempt to explain the need to include relationships into the analysis of internationalization processes is the business networks approach, which regards markets as networks of firms (Ford, 2002). According to this approach, the creation and development of relationships between the different actors of a network are crucial (Ford, Gadde, \& Håkansson, 1988). In

Susana Costa e Silva is Assistant Professor at the Catholic University of Portugal-Porto, Porto, Portugal. Eugénia Pacheco is Assistant on the Board of Directors at JAP Group, Porto, Portugal. Raquel Meneses is Assistant Professor and Carlos Brito is Associate Professor in the Faculty of Economics at the University of Porto, Porto, Portugal.

Address correspondence to Carlos Brito, Faculty of Economics, University of Porto, Rua Dr. Roberto Frias, 4200-464 Porto, Portugal. E-mail: cbrito@fep.up.pt 
fact, relationships gained importance in both the managerial and academic worlds. The recently revised model of Uppsala (Johanson \& Vahlne, 2009) embraces some of the main insights provided by the advent of the relationships' importance. This theoretical framework can be used to understand how relationships and the knowledge driven by it can influence internationalization processes.

The revised Uppsala model is based on the well-known model of Uppsala (Johanson \& Vahlne, 1977; Johanson \& Widersheim-Paul, 1975) that suggests that firms internationalize gradually and progressively. This means that there is a preestablished internationalization pattern: in terms of the entry modes used (from simpler to more complex modes) and in terms of the countries served (from closer to far distant countries). However, Ford (2002) suggests that despite the evidence of business practicality of the Uppsala model, empirical studies in the 1970s and 1980s did not accommodate this attitude. Suppliers were regarded as the protagonists of the transactions, and markets were considered to be built of a huge number of small and faceless actors at play, taken individually. Hence, new developments were brought up by a group of academicians to whom the market was seen as a net of relationships between different actors. This new approach is based on a continuum number of relationship exchanges among a small number of identified actors (Håkansson \& Snehota, 1995).

Here, the authors stress that companies establish relationships with suppliers, customers, and other stakeholders that are characterized by being close, complex, and durable (Ford et al., 1988; Håkansson, 1982; Håkansson \& Snehota, 1995; Hallén et al., 1991). The aim of this article is to understand how business relationships established by small and medium-sized enterprises (constrained by the liability of smallness) may influence their internationalization process and the knowledge resulting from it. In order to uncover this, we focus on the case of a firm that holds sales subsidiaries in the United States, Spain, and China, currently with more than 3,000 customers spread all around the world.

The article is structured as follows. The next section provides a literature review with a special emphasis on the evolution of the Uppsala model since its first version in 1977 . Then, we present our model and, in the section that follows, the methodology is described and justified. Then the case analysis is presented. The final section includes the main conclusion, limitations, and suggestions for further research.

\section{LITERATURE REVIEW}

The studies developed at the University of Uppsala on international operations of Swedish companies (Johanson and Vahlne, 1977; Johanson \& Widersheim-Paul, 1975) show that their domestic business relationships are frequently longstanding and affect their international performance. The basic structure of the model is based in the distinction between state and change variables, according to Figure 1.

When looking for explanations for the firms' internationalization process, knowledge is a central issue. According to the Uppsala model, the major obstacle to internationalization is the lack of knowledge about foreign markets. Firms can only overcome this constraint by learning. However, firms' own experience is considered the basic source of the learning process. Hence, the only way to obtain valuable knowledge about foreign markets is by internationalizing. "Only by doing business in a specific country is it possible to learn how customers, intermediaries, competitors, and public authorities act and react in different situations" (Johanson \& Vahlne, 2003, p. 90). Knowledge cannot be transferred either from a country to another, or from one actor to another, so only first-hand knowledge is considered valuable, "experience itself can never be transmitted, it produces a change - frequently a subtle change-in individuals and cannot be separated from them" (Johanson \& Vahlne, 1977, p. 30)., \& because perceived risk is inversely related to knowledge, more knowledge means more commitment and therefore less perceived risk. The original Uppsala model is built on the basis of these premises, which results in the idea of internationalization as a gradual process.

However, this internationalization model later received some criticisms, addressed mainly to its deterministic orientation, which the authors themselves acknowledged. In 2009, when 
FIGURE 1. Uppsala Model: Basic Mechanism of Internationalization-State and Change Aspects. Source: Johanson and Vahlne (1977).

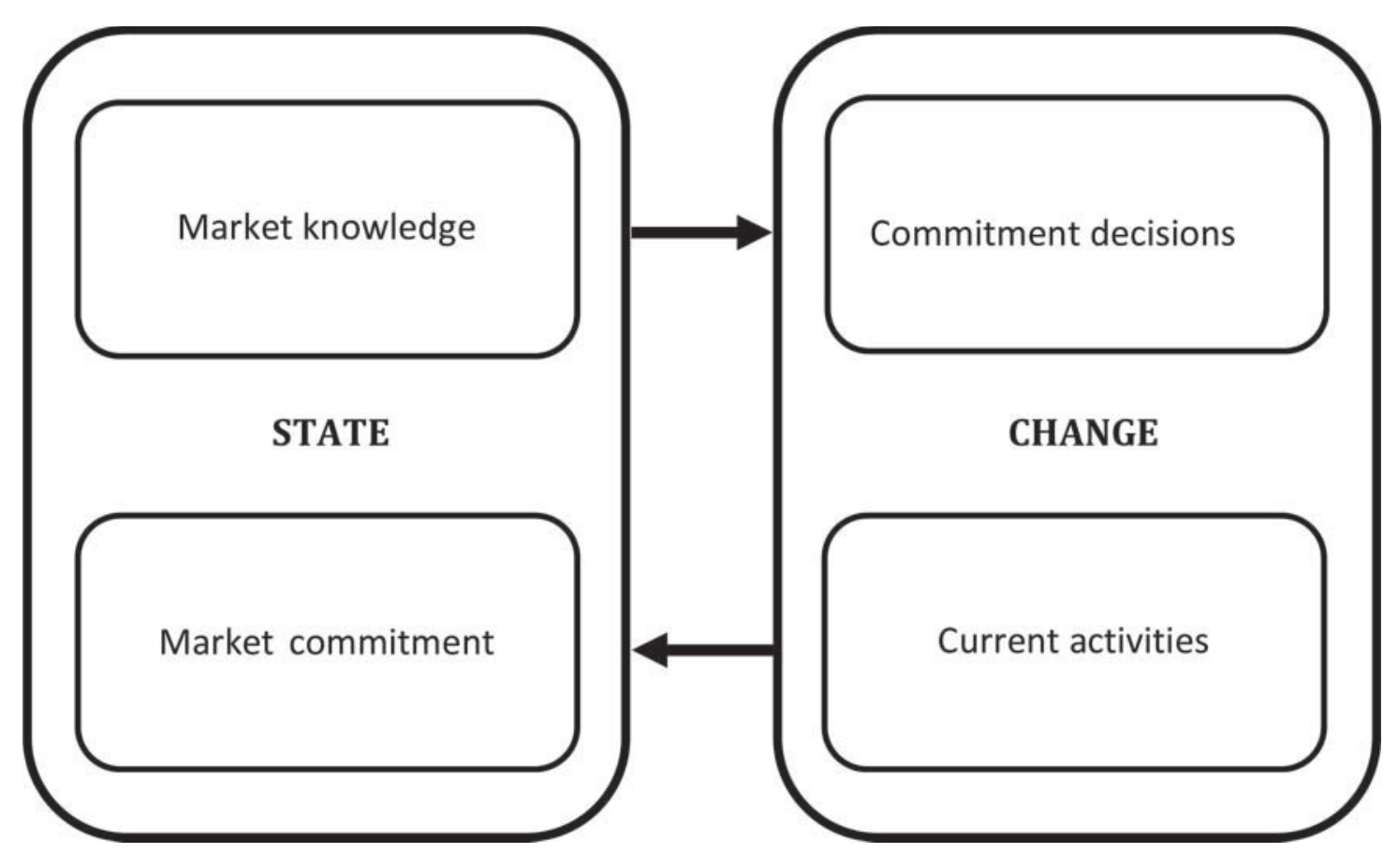

revising the model, Johanson and Vahlne had the chance to assess and update some of its premises and produce some counterarguments.

With reference to the establishment chain, the authors state that it was mainly used as an inspiration and should not be considered as a postulation of the model. In fact, in 2006 they clarified that the model is not about the establishment chain; this was the empirical phenomenon observed. "The model is on learning and commitment, or more precisely, on the interplay between knowledge development and increasing foreign market commitment" (Johanson \& Vahlne, 2006, p. 166). In some circumstances, "jumps" in the value chain are possible and acceptable. ${ }^{1}$ Moreover, regarding the phenomenon of "born globals," the authors state that even though it may seem to be incongruent with the assumptions of the model, it is not. The reasoning is that these firms first locate regionally. So, before being "born global," they are "born regional."

Another issue that was raised by some authors regarding the model was the relationship between psychic distance and the entry mode.
Concerning this issue, the authors consider that the link may indeed have weakened. This is due to the fact that some firms are now much more experienced in the international setting and have gained skills that allow them better to deal with internationalization. Additionally, similarly to Dunning (2001), Johanson and Vahlne (2009) came to the conclusion that joint ventures and strategic alliances are becoming a much more common way of internationalizing than was the case in the late 1970s. Thus, there is a fracture between the Uppsala model assumptions and managerial practice. In fact, the original model does not admit cooperation to be a driver of both market selection and operations mode decisions. However, in the 2009 article, the authors point out that empirical studies have shown that networks of relationships do indeed have an impact on the internationalization process of firms.

Additionally, the authors recognize now that internationalization is a multilateral process of developing relationship networks. This goes in line with the previous comments made to the model by authors such as Holm, Eriksson, and Johanson (1999), Johanson and 
Mattsson (1988), Johanson and Vahlne (1990, 2003, 2006), and Sharma and Johanson (1987), who also called attention to the importance of relationships. Since the 1990s, they have assumed that "the concepts "commitment, knowledge, current activities and commitment decisions" are "multilateral rather than unilateral as in the original model" (Johanson \& Vahlne, 1990, p. 19), so "the process is also interorganizational and not just interorganizational" (Johanson \& Vahlne, 1993, p. 51). The authors highly valuate these thoughts and tried to incorporate them into the model. They also highly regarded the Johanson and Mattsson (1988) internationalization model, which regards internationalization as the establishment and the development of positions of a firm in relation to other actors belonging to foreign networks. In fact, Johanson and Vahlne in 2003 tied their vision closer to the Network Theory, considering building and changing relationships as a critical issue. Hence, a firm's degree of internationalization can be inferred by the firm's position in a network and by the importance of that position in terms of relationships established. Many links and strong positions in a global network may foster the internationalization process.

We understand that the Uppsala model updated in 2009 incorporates the insights of the network theory. Johanson and Vahlne (1990) acknowledge this and therefore one can assume that they embrace the network approach of the IMP Group (Whitelock, 2002). In fact, when looking for explanations for the internationalization process of firms, the relation to other bodies (clients, suppliers, competitors ...) in the international market was considered by many academicians as very important., \& the same is true of the importance of a firm's experiential knowledge. These studies suggest that the interdependence and interaction between the actors of a network have an impact on how they relate and the configuration of the products traded (Håkansson \& Waluszewski, 2002). According to Welch and Welch (1996, p. 12), "an important part of a company knowledge is often created and maintained though actors in its relevant networks." Hence, networks mean information and experience flows. Therefore, firms can use second-hand knowledge (i.e., knowledge derived through other firms' experiences or observing the actions of the other actors), following a mimetic option of followingthe-leader (Haveman, 1993) or following-theherd. In imitative behavior, firms learn by observing other firms and acting in a similar way (see, for example, Haunschild \& Miner, 1997; Huber, 1991; Levitt \& March, 1988). "As ideas and practices are diffused among organizations, there is no reason why similar processes should not be present regarding the internationalization behavior of firms" (Forsgren, 2000, p. 10).

Organizations tend to imitate actions that had had a good result with a large number of other organizations, because their success is "taken for granted" (Haunschild \& Miner, 1997; Haveman, 1993; Kraatz, 1998; Levitt \& March, 1988). Therefore, firms can follow-theherd (learning with others' experience) using second-hand knowledge. In fact, firms can, also, gain access to the knowledge by following-theleader. Learning with high legitimacy firms (the successful ones) reduces its perceived uncertainty about foreign market. Firms can also learn through their partners: "It has been shown that access to a network of business relationships creates the opportunity to learn from other firms" (Forsgren, 2000, p. 112). This is significant because using this second-hand knowledge, firms can reduce international perceived risk without having to wait until they develop first-hand knowledge (derived from their own experience).

Another important insight of the revised model is that, while in 1977 Johanson and Vahlne admitted that uncertainty (via psychic distance) was an important factor in the decision of the entry mode to use, when adding a business network perspective to the analysis, they admit that uncertainty results mainly from the absence of a strong position of the firm in its network. In fact, they assume that relationships have considerable influence on the selection of foreign markets and on the entry modes to use. Essentially, by being linked to a great number and variety of agents, firms must be exposed to a great number and variety of knowledge sources. If a weak position is held, the knowledge shared is smaller and the level of uncertainty higher. On the other hand, if a strong position is held, partners will tend to have more access to more 
knowledge, which diminishes the uncertainty. This is due to the development of knowledge and commitment that take place within the relationship., \& because some types of knowledge are only accessible within the network (because it is tacit), being part of a network is important and having a strong position in that network is even more important. "A firm's success requires that it be well established in one or more networks [...] it is to a large extent via relationships that firms learn, and build trust and commitment- the essential elements of the internationalisation process" (Johanson and Vahlne, 2006, p. 5). This may allow these firms to be more aware of opportunities and threats in the environment and, additionally, to be better prepared to go beyond the liability of foreignness in international markets (Zaheer, 1995).

All of this considered, Johanson and Vahlne revised the model proposed in 1977 and modified the variables of state as well as the variables of change (Figure 2), by considering the following:

- "Knowledge opportunities" (instead of "market knowledge"). Authors highlight that there are other types of valuable knowledge: needs, capabilities, strategies, and networks, but opportunities are the "most important element of the body of knowledge that drives the process" (Johanson \& Vahlne, 2009, p. 1424).

- "Network position" (instead of "market commitment"). This concept is characterized by "specific levels of knowledge, trust and commitment that may be unevenly distributed among the parties involved, and hence they may differ in how they promote successful internationalisation" (Johanson \& Vahlne, 2009, p. 1424).

- "Relationships commitment decisions" (instead of "commitment decisions"). This notion is adapted from the original model to underline the idea that commitment is to relationships.

- "Learning, creating and trust-building" (instead of "current activities"). This is a way of clarifying the output of current activities. As in the original model, learning plays an important role (not only the experiential learning). Creating highlights the

FIGURE 2. The Basic Mechanism of Internationalization: State and Change Aspects-The Business Network Model. Source: Johanson and Vahlne (2009).

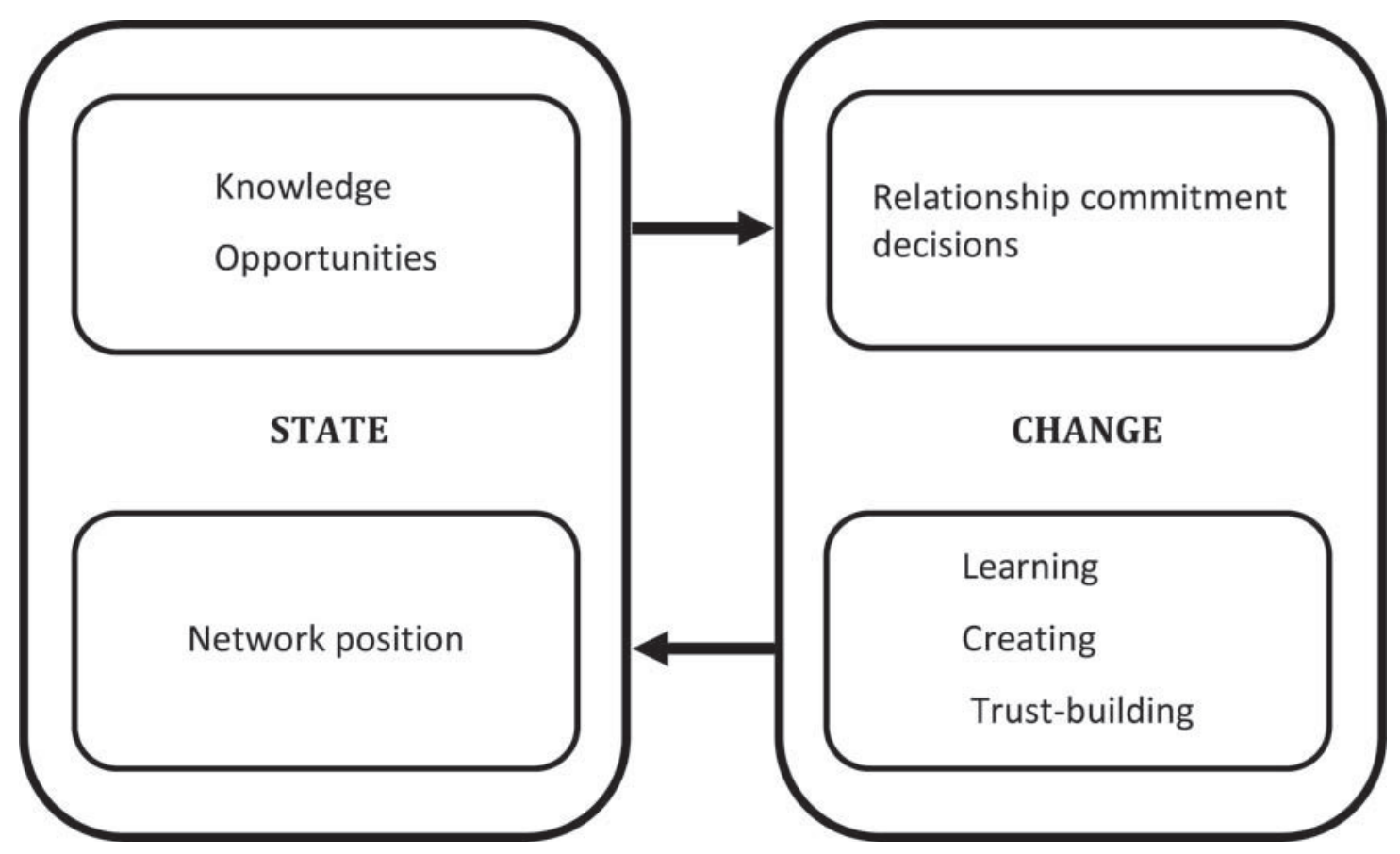


idea that interfirm activities create knowledge and opportunities, and trust-building stresses that all the processes may be facilitated by trust.

Variables affect each other, with the current state variables influencing the change variables, and vice versa. An increase in the level of knowledge will produce positive or negative influences on trust building and commitment. These processes can occur on both sides of a relationship in any part of the network from which the focal firm is member. Network position reflects the quality and variety of relations; it reflects bridges to other agents and it influences firms' relationship commitment decisions, which affects the network position.

In terms of the implications of this new version of the model for the internationalization explanations, we may say that international relations can be considered, simultaneously, as the explanatory and the explained variable. Going international and the degree of internationalization thus depend on the relationships the firm establishes with national or international partners. Thus, it is expected that the company internationalize its operations where it, or its partners, detects opportunities. If the company does not have yet relevant partners in foreign markets, the alternative is to go where it is easier to connect to a company already positioned (maybe an agent or a distributor)., \& this is how the internationalization process may start. As the internationalization process is carried out, firms must make decisions about relationship commitment and they must learn one to each others, creating more connections and building trust. As result, firms get more commitment with the market and, simultaneously, knowledge and opportunities to gain knowledge improve. Therefore, internationalization is regarded as a self-sustaining process. Eventually, as time goes by and relationships develop, the company will be able to eliminate the middleman and create a subsidiary., \& this is how the revised model explains situations of extending already existent internationalization processes.

\section{MODEL}

Considering this network approach in the internationalization process of a firm (Figure 3), we may thus claim that the beginning of the process is arbitrary. Just the process itself may be knowable, not when it starts. That implies that we have no means to tell when the internationalization process is going to start, because it will depend on state variables. This could raise the issue of the "born global" again since they claim that the model has difficulties predicting when the internationalization process is going to start. However, they also claim that state variables can determine this and we know that state variables include knowledge and that knowledge is made up of experiences.

In this line, Johanson and Vahlne (2009) restate that it is experience (firm and partners' experience), and not the size of the firm, that defines the internationalization process since its beginning. This is the reason why we may say that experience is critical in this model. In fact, firms sometimes follow-the-herd or follow-theleader; firms learn through the imitation of other organizations-network partners. So, the relationship development should also be included in a model of internationalization behavior. Firms can use bridgehead partners to develop new relationships in the foreign market, and firms can learn with the old and the new partners.

As firms internationalize, they are learning about their markets (first-hand knowledge) and frequently this occurs through their business networks (second-hand knowledge). As firms internationalize, they develop relationship and experience and through both they acquire the necessary knowledge to internationalize.

\section{METHODOLOGY}

\section{Unit of Analysis and Variables}

Considering the problem that we wanted to address - how can relationships influence firms' internationalization process-relationships and experience may be considered the independent variable and the internationalization process the dependent one, as displayed in Figure 4. 
FIGURE 3. The Internationalization Process on the Basis of Experience and Relationships Development (Color Figure Available Online)

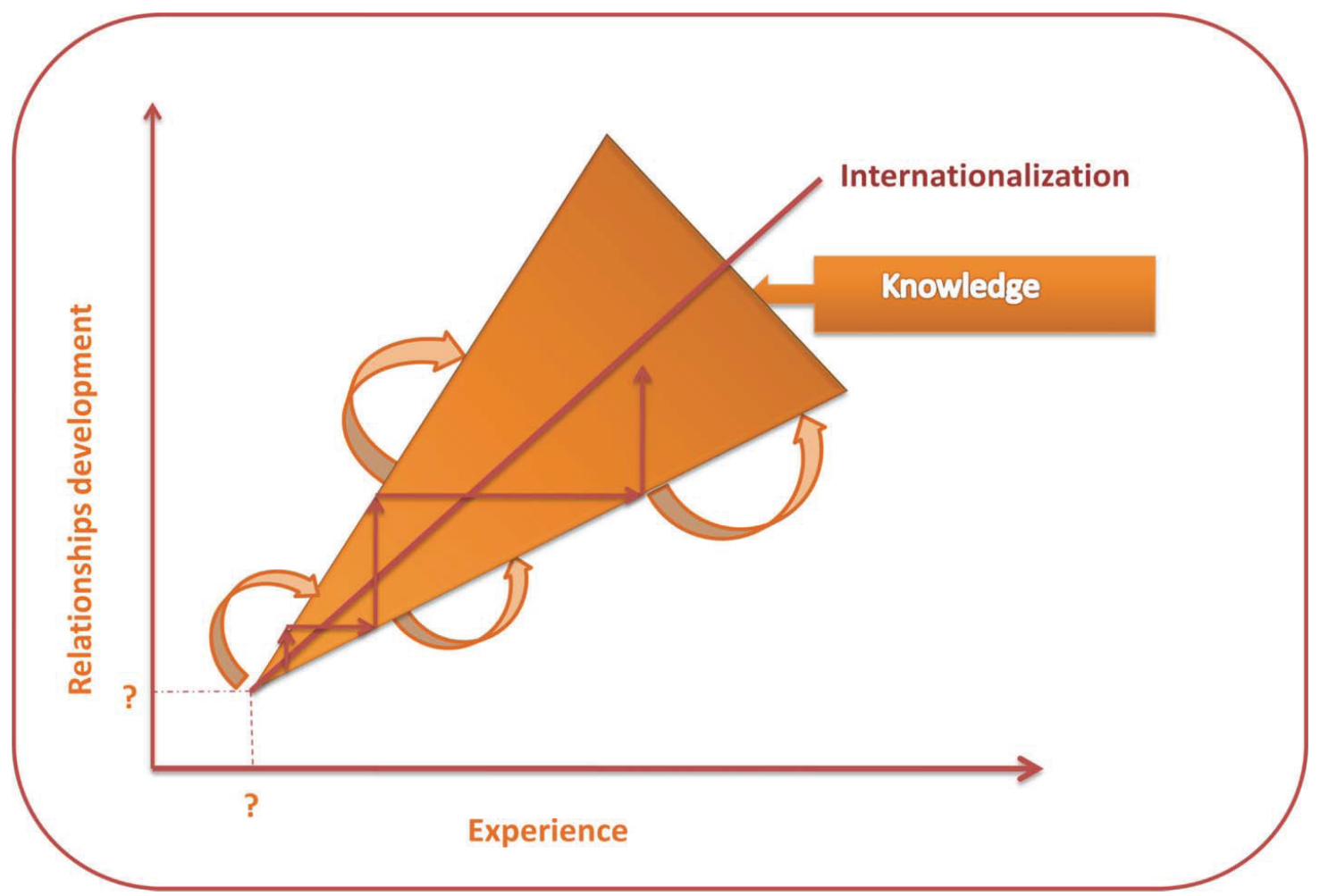

FIGURE 4. Internationalization and Relationships Development (Color Figure Available Online)

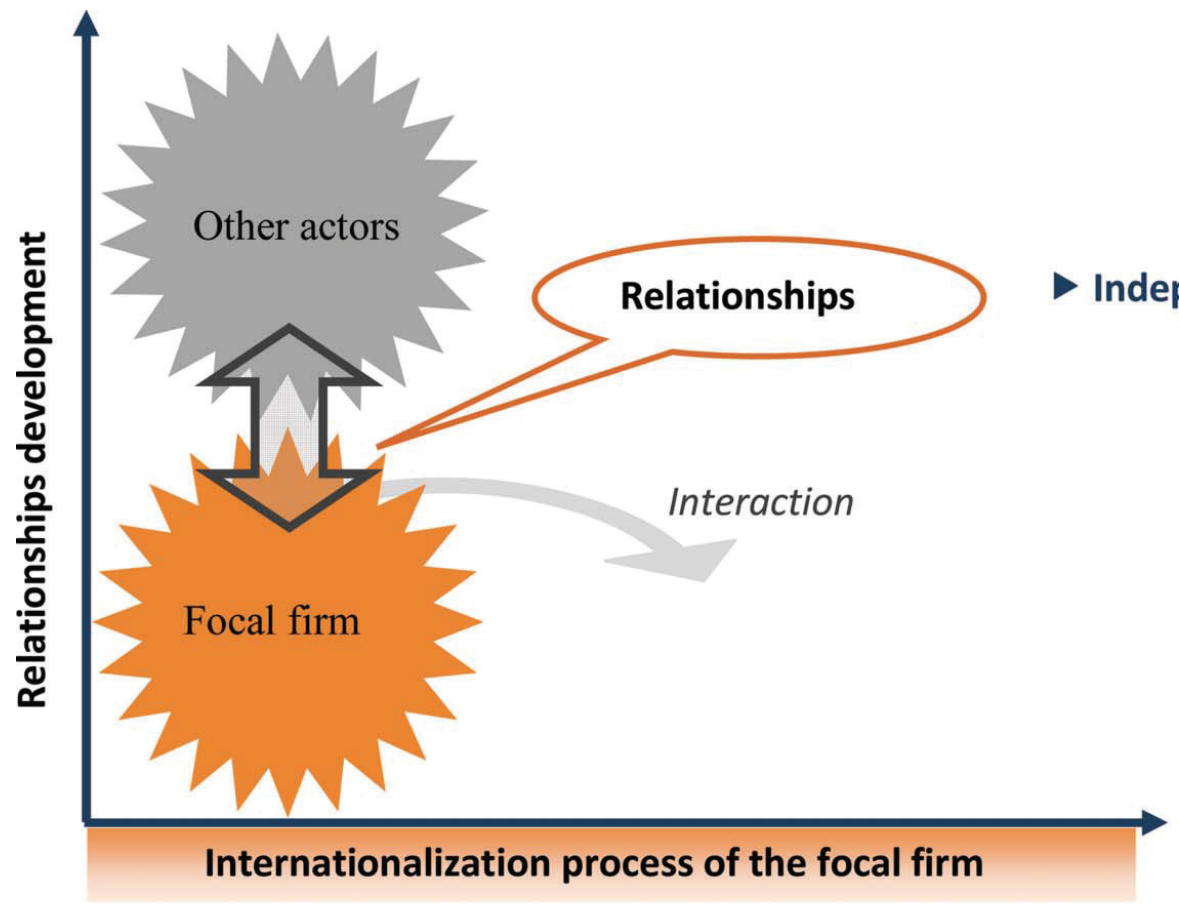

Dependent variable 
According to Johanson and Vahlne, the premises of the model consider that rationality is limited and that gaining access to a business network is necessary for the development of business. In fact, relationships offer a potential for learning, trust-building, and commitment, which are considered preconditions for internationalization. Consequently, we admit that market selection and market entry modes are influenced by the existing and prospective relationships of a firm. Additionally, it is considered that the sum of factors hindering the flow of information from and to the market, that is, the psychic distance among partners, is going to affect the type of relationships that firms are going to establish. The main underlying idea is that psychic distance between the individuals who represent companies is likely to impact the process of accessing relevant networks.

Firms own both tangible and intangible resources, and they can also access other network firms' resources through relationships. Thus, regarding resources, one can say that a focal firm can get access to resources it does not own but that belong to network members, through relationships.

With regard to experiences, one can say that they provide knowledge that can be controlled and shared by actors at play. Raises in the level of knowledge of one firm can positively or negatively impact trust building and commitment. Ideally, learning, trust-building, and commitment would reinforce a firm's position in the network. Commitment with partners may increase a firm's knowledge and therefore facilitate a better recognition of business opportunities. Consequently, the internationalization process may be fostered through partner commitment. So it is important that there is a minimum (unknown) level of experience and relationship commitment between partners for the internationalization process to start.

Henceforward we may understand internationalization as a virtuous circle. The internationalization process depends on the network position of a firm. Relationships are bridges to international opportunities. If a firm has a strong network position (connected with a lot of different partners who have different experiences and connections), it has indirect access to partners' knowledge. So, as a firm combines its own knowledge from its own experiences (first-hand knowledge) with partners' knowledge (second-hand knowledge), ${ }^{2}$ it will have the necessary conditions to internationalize. According to Johanson and Vahlne (1990, p. 20), internationalization is the "process of developing networks of business relationships in other countries through extension, penetration, and integration." Therefore, starting internationalization creates the necessary conditions for its development, in a self-sustaining and virtuous process.

\section{The Case Study Approach}

We aim to study how firms' relationships may influence their internationalization process, namely their international operation modes and their international geographic expansion. When issues under analysis involve a "how" type of question, when the researcher has no control over events, and when the focus is on a contemporary phenomenon in a real context, Yin (2003) advises the use of case studies.

The proposed case study is based on Abyss $\&$ Habidecor (A\&H), a Portuguese textile company. In the past, the textiles sector was a cluster where Portugal had a competitive advantage on the basis of low labor costs along with the WTO's restrictions on textile exports from developing countries. However, this scenario has changed: nowadays Portugal no longer holds such a competitive advantage, and Chinese textiles are invading the domestic market. Thus, A\&H's experience in this sector, namely in what concerns its internationalization process, seemed to be very interesting. The company is not just deepening its international presence, but it is able to export to China.

According to Yin (2003), the use of many sources of evidence is advised to produce a good case study. Thus, we tried to collect primary and secondary data from different sources. We conducted a semistructured interview with A\&H's senior manager in Portugal, at the company's factory and head office in Viseu, on October 29, 2008. This data collection method was chosen in order to give the interviewee more flexibility to respond and express his thoughts, allowing unanticipated themes to emerge, thus 
providing richer data than a less open framework would permit. The interview session of about 5 hours was audio recorded and later transcribed. The in-depth interview was complemented with two subsequent short telephone interviews on September 7 and November 2, 2009.

Data were also collected through examination of written documents (organizational documents, press articles, websites, and photographs). We also collect data through direct observation of behaviors and organizational activities. The nature of the data collected was both qualitative and quantitative. Content analysis was used, as well as a data triangulation technique, as proposed by Yin (2003). In the following section, we proceed to the case description, based on data collected.

\section{THE ABYSS \& HABIDECOR CASE STUDY}

\section{The Beginning}

In the late 1960s, the co-founders of A\&H took off to Belgium where, after a period of studies in textile engineering, they began their activity in the textile sector working in the Tournai tapestry industry. On returning to Portugal in the mid 1970s, drawing on the experience and contacts developed in Belgium, the two boyhood friends became independent sales agents for several Portuguese textile firms. Soon afterward, they started up their own bathroom floor mat manufacturing company: Abyss \& Habidecor. Although the goal of A\&H was, from its foundation, to serve the international market, in its early stage of development, products of the small firm based in Viseu were primarily sold in the domestic market.

The participation in textiles trade fairs boosted the development of A\&H's network of contacts internationally, which generated new business opportunities. Through preestablished contacts with foreign wholesalers and agents, A\&H started its international activity via direct exports, predominantly to Western Europe, most notably to Germany, France, Belgium, Switzerland, the United Kingdom, Italy, and Spain. A\&H produced in large volumes, at relatively low cost per unit, to fulfill orders from whole- salers to whom price was a determinant factor in their buying decision.

The "strategy of selling cheap" allowed A\&H to rapidly increase its sales volume and grow. However, it left the company in a position of deep dependence and weak bargaining power with big intermediaries, which kept its profit margins down. The state of dependence was further imbalanced after the WTO's Agreement on Textiles and Clothing, which dealt a death blow to many Portuguese textile firms.

This adverse scenario led A\&H to rethink its business strategy and invest in the development of a new, less price-sensitive, value proposition, which would ensure its long-term survival in the market. Thus, in order to set itself apart from direct competition with the new players, A\&H redirected its product to high-end market segments. Pursuing a niche strategy, A\&H made a clear bet on increasing the level of differentiation of its market offering. They did this by investing in product design, the use of quality materials, the aggregation of a service component, and extensive investment in its brand image, thus adding intangible value to it. The strategic reorientation implied the repositioning of A\&H's brand, which impelled the firm to seek new partners and develop new business relationships.

\section{The U.S. Market: Agent and Sales Subsidiaries}

At the end of the 1980s, A\&H began exploring business opportunities in the United States by participating in a textiles fair in New York, where it established contacts with an independent local sales agent, based in New Jersey, with experience and business contacts in the East Coast (Figure 5). In close collaboration with the American agent, A\&H progressively started to export its products to the U.S. market. Exports to the United States grew very slowly in the first 4 years but began to pick up pace later. In 1992, A\&H established a sales subsidiary in New Jersey, inviting the trusted local agent to run its U.S. branch. The U.S. subsidiary activity is currently focused on managing the American accounts and on the development of local business relationships. Presently, A\&H exports to the United States stand for about $25 \%$ to $30 \%$ of its global sales. 
FIGURE 5. Summary of A\&H Internationalization Activity in the United States

1988

- Started exporting to the U.S. through a pre-established contact with a local agent.

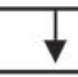

1992

- Established a fully owned sales subsidiary in New Jersey to support and develop business relationships with U.S. retailers.

- The former independent agent was invited to run the U.S. office.

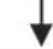

\section{2}

- Opened a second U.S. sales subsidiary, in a strategic alliance with an important client (i.e., set up an A\&H shop on the 3rd floor of ABC Carpet \& Home department store in New York). 
FIGURE 6. Summary of A\&H Internationalization Activity in Spain

\section{0}

- Stated direct exports to Spain through preestablished contacts with local retailers.

\section{4-currently}

- Established 20 corners in stores of a retail chain across Spain, within the context of a long-term relationship.

\section{The Spanish Market: Direct Export and Sales Subsidiaries (Shop-in-Shop)}

A\&H has since 2004, and at their initiative, established 22 corners at El Corte Inglés stores across Spain and Portugal (Figure 6). This happens within the context of a long-term relationship-since the early 1980s-with El Corte Inglés, Spain's leading department store chain.

Based on this experience with El Corte Inglés, A\&H developed similar partnerships with a retailer in Japan, another one in Belgium, and yet another one in Switzerland.

\section{The Chinese Experience: Sales Subsidiaries}

China's opening-up policies and economic reforms heralded fresh opportunities and challenges to economic agents. In 2003, A\&H established a relationship with a Chinese business consultant in Beijing through one of its Portuguese contacts (Figure 7). The local business consultant, who had experience in organizing inbound business missions to China involving Portuguese entrepreneurs and official representatives, has played a very important role in $\mathrm{A} \& \mathrm{H}$ venture into China, acting as liaison with Chinese contacts and facilitator.

During his business trips to China, planned out with the local consultant, the A\&H Group president established contacts with a household products retail firm, which became a client. Embracing a business opportunity detected by the client, A\&H opened its first store in China in December 2005. Since then, that local partner- ship flourished in the form of 11 additional A\&H brand stores in China. The local partner provides the space and service and manages the stores, while A\&H supplies the products and invests in merchandising equipment and promotional activities.

Regarding the Chinese market, A\&H understands that it is essential to gain the trust of partners in order to develop successful business relationships. Personal contacts are essential to get to know and build trust with business partners. Obviously, partner selection is also crucial and the company acknowledges that. Also, the quality of their branded products and excellent distribution systems is fundamental.

We can say that the relationship with the Chinese partner has reached a stable stage. Together, they have $12 \mathrm{~A} \& \mathrm{H}$ stores in China. Even so, A\&H believes that the Chinese market has much more potential. In 2008, the Chinese market represented only $5 \%$ of A\&H's sales and A\&H is currently working together with the Chinese partner on increasing the sales. The firm is also committed to finding new opportunities in smaller but attractive Chinese cities, where the middle- and upper-middle classes are expanding. The firm believes that its knowledge of the Chinese market, along with its experience and the relationships established, should provide a good ground from which to launch a sales subsidiary. China is regarded as a flourishing country for A\&H products. However, that is not true on an outsourcing point of view, from which China does not look so appealing. In fact, A\&H believes the expertise on which they base the quality of their products is only available in 
FIGURE 7. Summary of A\&H Internationalization Activity in China

\section{3-2005: Development of contacts}

- Detected an opportunity to expand its business to the Chinese market.

- Established a relationship with a local business consultant through a contact in Portugal.

- A\&H managers traveled to China several times to meet potential partners, identified by the local consultant.

- Began exporting punctually, through a business relationship developed with a big local retailer.

December 2005-2009: Opened 12 A\&H brand stores in China with a local partner

- In a strategic alliance with the local client, and by the client's initiative, opened since December 2005, 12 A\&H brand shops in mainland China, Taiwan, and Hong Kong.

- A\&H reached a new agreement with the local partner: It will continue supplying the existing A\&H shops, but it will disinvest in them. 
their headquarters. On another hand, Portuguese products or brands seem not to have a major disadvantage in the Chinese market, compared with other products originated in countries that may benefit from a better country-of-origin effect. The important thing here is to have opened a store in one major city like Paris, New York, or London, because Chinese clients get inspiration in reference cities.

\section{DISCUSSION AND FINDINGS}

In this article, we addressed the fundamental question of how relations can influence the internationalization process, using a Portuguese case to illustrate the point. We focus our analysis on the Uppsala model (Johanson \& Vahlne, 1977, 1990, 1993, 2003, 2006, 2009) and the network approach (Hadley \& Wilson, 2003; Johanson \& Mattsson, 1988; Johanson \& Vahlne, 2009).

We were able to understand (Table 1) that a firm starts exporting to psychically near markets (Europe), by means of its experiential knowledge (first-hand knowledge), and using exports only, a very simple entry mode. However, as time goes by, and experience increases, it is time to move forward to locations where firm has no experiential knowledge yet, in which case it uses second-hand knowledge. To internationalize to the United States, A\&H went first to trade fairs and there established contacts. Through those contacts, it got second-hand knowledge (using partners' experience) to get information about opportunities in more distant markets. To internationalize to China, the firm established a relationship with a Chinese business consultant in Beijing using one of its Portuguese links. It used relationships to begin exporting and move afterward to a sales subsidiaries approach.

As internationalization evolves, A\&H develops trust in their partners., and when this happens, the firm gathers the conditions to move to more complex modes of internationalization.

\section{The International Geographical Expansion of $A \& H$}

A\&H has mainly gone through three stages in its internationalization process (Figure 8).
First, the firm was just producing and selling in the domestic market even though with a clear intention of exporting. The firm started exporting 3 years after its foundation and did it to geographically and psychically closer countries, in Europe. Afterward, it expanded its international activities to other countries, namely the United States and China, which are far geographically and very far psychically.

\section{The Entry Modes Used by A\&H}

With regard to the foreign operations modes used, A\&H started with direct export and continued to do so during the second internationalization stage. In the later stage of its internationalization process, with a reduction in the perception of uncertainty, with trust built in local partners and with an increase in the ability to detecting opportunities, the firm also started to use sales subsidiaries. Still, it did it simultaneously with the export modes.

In the third stage, some intermediaries were eliminated. The firm got better and quicker information from the market, and this fostered its ability to respond to market trends. The internationalization process was gradual and progressive, not just geographically but also in terms of the entry mode used. In Table 2, we combine entry modes and markets selected.

Our research extends the internationalization Uppsala theory by combining it with the network approach. In the original Uppsala model, Johanson and Vahlne (1977) posit that the main obstacle to the internationalization of a firm is the lack of knowledge about the foreign market. This means that firms would only be able to obtain that knowledge through their own experience of operations in foreign markets (i.e., learning-by-doing). This was the reason why according to the first version of the Uppsala model internationalization had to be done progressively and gradually. In short, the experiential knowledge was considered as a key driver to internationalization. Consistent with that view, they analyzed firm starts as a domestic firm, and then it gets some exports. It internationalizes to neighboring countries using its experiential knowledge. 
TABLE 1. Synthesis of Abyss \& Habidecor International Activity

\begin{tabular}{|c|c|c|c|c|c|}
\hline Year & Market & Entry mode & Major opportunities detected & Major threats perceived & Balance \\
\hline 1977 & Domestic & Sales to retailers & - Sales & - Very small market & - \\
\hline 1980 & Europe & Direct export & $\begin{array}{l}\text { - Geographically/psychically close to } \\
\text { domestic market } \\
\text { - Huge market } \\
\text { - High purchasing power }\end{array}$ & $\begin{array}{l}\text { - 1990's: new competitors from } \\
\text { developing countries } \\
\text { - Deep dependence from } \\
\text { wholesalers }\end{array}$ & ++ \\
\hline 2004 & Spain & $\begin{array}{l}\text { Establishment of } 20 \text { corners in a } \\
\text { retail chain }\end{array}$ & $\begin{array}{l}\text { - More visibility and sales } \\
\text { - Strengthening of relationship with } \\
\text { important client }\end{array}$ & & \\
\hline 1988 & U.S. & Direct exports through sales agent & $\begin{array}{l}\text { - Big market } \\
\text { - High purchasing power } \\
\text { - Motivated agent }\end{array}$ & $\begin{array}{l}\text { - Lack of market knowledge in } \\
\text { the early stage } \\
\text { - Geographically distant }\end{array}$ & $\begin{array}{l}++ \\
++\end{array}$ \\
\hline 1992 & & Sales subsidiary & - Strengthening of market position & & ++ \\
\hline 2002 & & $\begin{array}{l}\text { Establishment of } 1 \text { shop in a } \\
\text { department store }\end{array}$ & - Strengthening of market position & & ++ \\
\hline 2005 & China & Direct exports with partnership & $\begin{array}{l}\text { - Economic opening-up } \\
\text { - Huge market }\end{array}$ & $\begin{array}{l}\text { - Lack of market knowledge } \\
\text { - Geographically distant }\end{array}$ & + \\
\hline - & $\begin{array}{l}\text { Other (e.g., Japan, Canada, } \\
\text { UAE, Lebanon, Brazil) }\end{array}$ & $\begin{array}{l}\text { Direct exports (agents in South } \\
\text { Korea, UAE, Japan) }\end{array}$ & - Sales growth & & + \\
\hline
\end{tabular}

Note. - Means negative; + means positive; and ++ means very positive. 
FIGURE 8. Stages of A\&H's Geographical Expansion
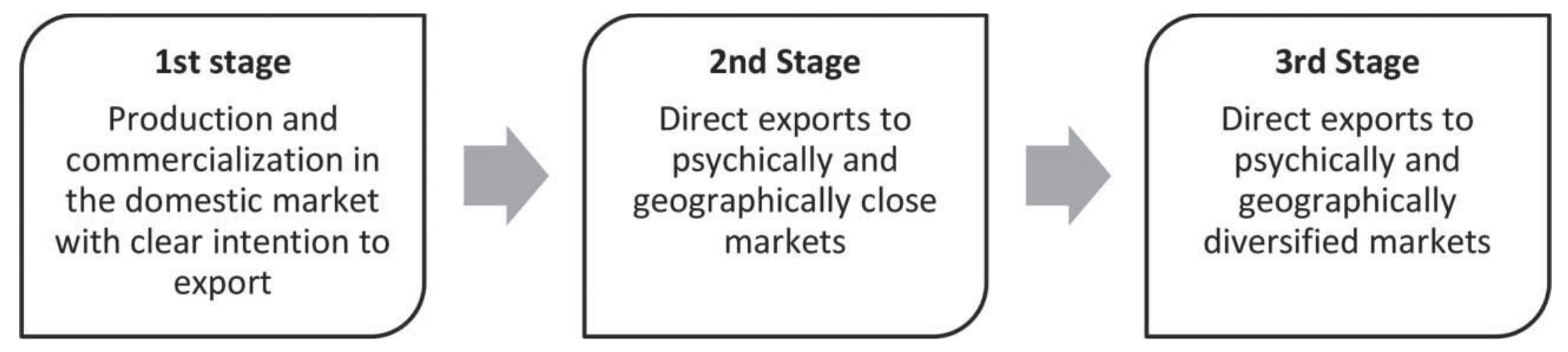
TABLE 2. Synthesis of Market Selections and Entry Modes

\begin{tabular}{|c|c|c|}
\hline Stage (years) & $\begin{array}{l}\text { International geographical expansion firm: Abyss \& Habidecor, } \\
\text { founded in 1977, Viseu, Portugal }\end{array}$ & $\begin{array}{l}\text { Entry modes } \\
\text { (export modes only) }\end{array}$ \\
\hline Stage $1(0-2)$ & $\begin{array}{l}\text { Focus on the domestic market with the clear intention to export } \\
\text { - Establishment of relationships with European intermediaries through the } \\
\text { participation in textile trade fairs and owner-managers' personal contacts }\end{array}$ & $\begin{array}{l}\text { - Commercialization in the domestic market } \\
\text { - Direct exports to wholesalers and through sales agents }\end{array}$ \\
\hline Stage $2(3-14)$ & $\begin{array}{l}\text { Predominance of exports to geographically/psychically close markets } \rightarrow \text { Europe } \\
\text { - Beginning of international activity via direct exports to European markets } \\
\text { through preestablished relationships with reseller and sales agents } \\
\text { - Intensification of exports to European markets } \\
\text { - Increasing exports, albeit meagre, to geographically more distant markets, } \\
\text { through occasional contacts made in major European trade fairs. } \\
\text { - Stagnation of exports to Europe. } \\
\text { - Has begun to evaluate possibilities of diversifying its export markets } \\
\text { - Proactively explores opportunities to enter in the U.S. market by participation in } \\
\text { a local textiles trade fair, where it established a relationship with a sales agent. }\end{array}$ & \\
\hline Stage $3(15-32)$ & $\begin{array}{l}\text { Exports to geographically diversified markets } \rightarrow 5 \text { continents } \\
\text { - Rapid growth of exports to the U.S. market and opening of a sales subsidiary in } \\
\text { New Jersey } \\
\text { - With the liberalization of world trade of textiles, and growing competition from } \\
\text { manufacturers in developing countries, A\&H diversifies and reorients its } \\
\text { market offer to high-end segments, adopting a niche strategy, which impels the } \\
\text { firm to diversify its export markets } \\
\text { - Develops a progressively more complex network of business relationships, with } \\
\text { resellers, sales agents, corporate clients (hotels, spas, etc.) and consumers in } \\
5 \text { continents. } \\
\text { - Approximately } 40 \% \text { of A\&H exports are to Europe, } 25 \% \text { are to the U.S., and the } \\
\text { remaining } 35 \% \text { are to several other markets (South Africa, Egypt, Morocco, } \\
\text { Argentina, Brazil, Canada, Mexico, Saudi Arabia, China, South Korea, UAE, } \\
\text { Israel, Jordan, Lebanon, Singapore, Australia, and New Zealand) }\end{array}$ & $\begin{array}{l}\text { - Direct exports to wholesalers and retailers and through sales } \\
\text { agents (years 3-32) } \\
\text { - Establishment of } 1 \text { sales subsidiary in the U.S. (year 15) } \\
\text { - Establishment of } 20 \text { sales corners in Spain and } 2 \text { in Portugal, in } \\
\text { partnership with } 1 \text { Spanish client (years 27-32) } \\
\text { - Establishment of } 1 \text { shop in the U.S., in partnership with } 1 \text { local } \\
\text { client (year 25) } \\
\text { - Opening of } 12 \text { stores in China, in partnership with } 1 \text { local client } \\
\text { (years 28-32) }\end{array}$ \\
\hline
\end{tabular}


FIGURE 9. The Influence of Knowledge on the Internationalization Process According to the Uppsala Model (Original and Revised; Color Figure Available Online)

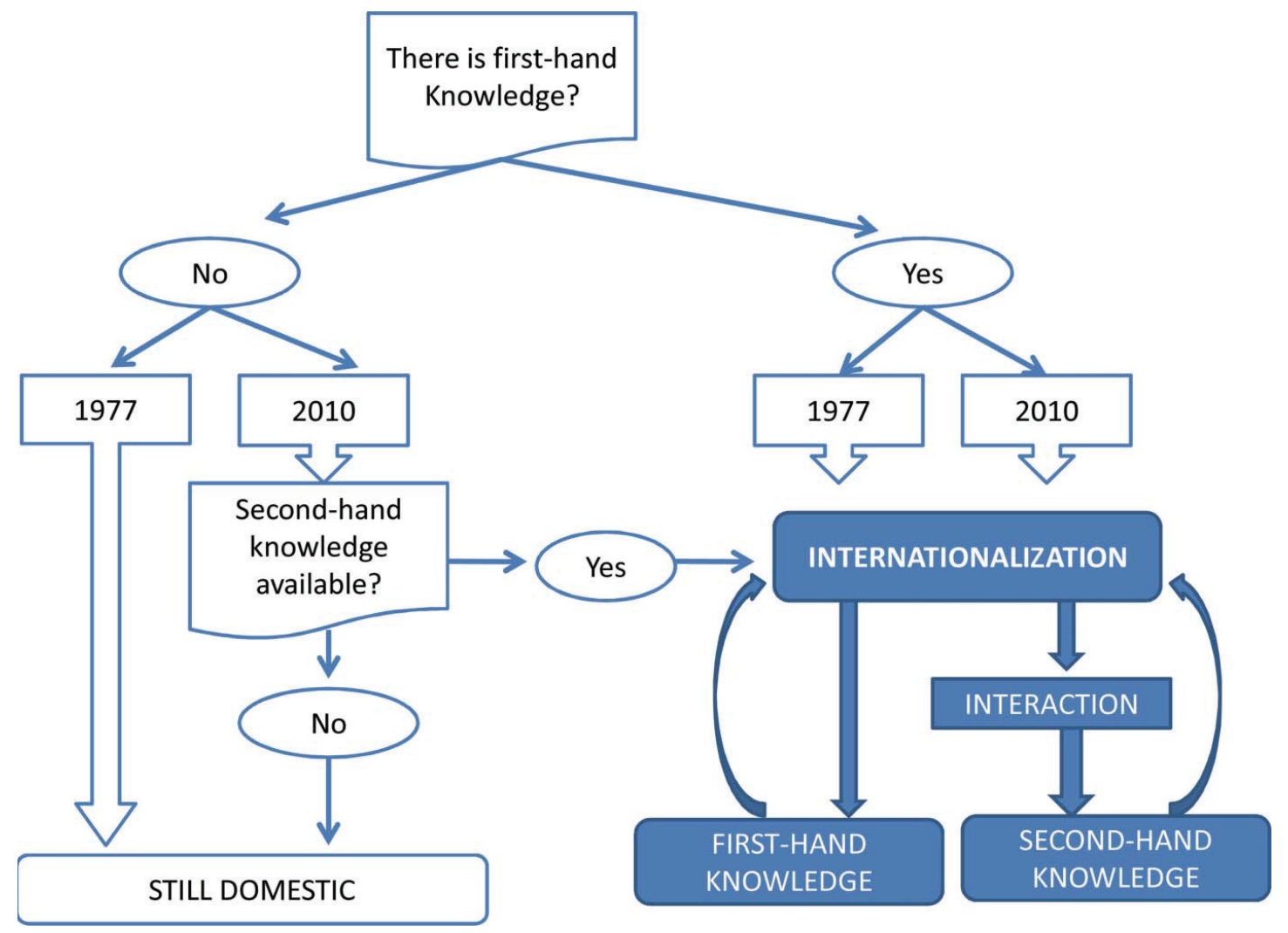

According to the network approach, firms use their partners as a knowledge source. This is considered as second-hand knowledge that results from partners' experience. Yet consistent with this approach, the firm uses this kind of knowledge to expand further, into places where it does not have experiential knowledge (Figure 9).

A\&H used its own experience to internationalize to Europe, namely at first place to Spain (a market considered closer). When it detected an opportunity in more distant markets (geographically and psychically), it did not stopped because it did not have enough knowledge. For example, in China, A\&H established a relationship with a local business consultant though a contact in Portugal.

It used the contact's knowledge to meet a Chinese consultant and it used Chinese consultant's knowledge to internationalize there. So, when it had had knowledge through its own experience A\&H used it; when it did not had first-hand knowledge (from a previous experience), it used second-hand knowledge (through partner's experience)

In line with the Uppsala model, in all markets $\mathrm{A} \& \mathrm{H}$ begins with exports (a simple entry mode), and in line with the revisited Uppsala model, as internationalization evolves it learns, creates more opportunities, and-very important-it evolves in a trust-building process with its partners. In doing it, it obtains secondhand knowledge. So it passes to the next stage with more complex international modes.

\section{CONCLUSION}

This case encompasses both theoretical and managerial findings. In what concerns theoretical ones, we can argue that first-hand knowledge as the first source of knowledge is used when going international. Frequently this means 
going to psychically closer markets. Second, second-hand knowledge (resulting from partners' experience) as a source of international knowledge is used in case of a lack of firsthand knowledge. In a recent work, Bruneel et al. (2010) argue, following the same line, that "interorganizational learning" (i.e., from where our second-hand knowledge comes from) is an important mechanism through which business relationships influence internationalization process. Frequently, this type of knowledge encourages the decision to move to more distant markets. Third, internationalization can be regarded as a snowball process due to the internationalization process itself that allows the development of conditions: learning, opportunity creation, and trust-building. So, it is a self-sustaining process in stages.

From a managerial standpoint, our article also highlights the strategic importance of networks as sources of knowledge. These sources allow a firm to gain foreign market access and, in time, to gain international capabilities through and with the partners.

Nonetheless, this study has some limitations, thereby providing avenues for future research. First, it is based on just one case, raising the question of whether our results would hold in other firms or reflect an idiosyncratic situation. We believe that further studies of more firms in different sectors and countries would help to generalize our findings.

Factors such as partners' location (national and foreign), the specific type of business relation (agent/client/distributor, formal/informal), personal relationships, and the relative absorptive firm capacity (Cohen \& Levinthal, 1990) could also be introduced in future research.

The research design also does not allow for testing the different roles played by the entrepreneur's knowledge and the firm's knowledge. Indeed, we treat in our study all previous knowledge as the firm's knowledge and we do not clarify the situation in which the knowledge is transferred from the entrepreneur to the firm. In fact, there might be differences between the knowledge as experienced by the firm and the entrepreneur. If the knowledge is experienced by the entrepreneur, there is no guarantee that the firm absorbs it throughout and entirely. So, other studies may focus on this query in the future.

While beyond the scope of the current study, future research should examine the conditions under which second-hand knowledge (resulting from interorganizational learning) is interpreted and fully absorbed by the firm. Indeed, knowledge acquired from partners results from their experience and, according to Baum, $\mathrm{Li}$, and Usher (2000), it might not be directly applicable to the focal firm. It requires interpretation and, as in any case where interpretation is needed, personal values and perceptions would have to be used, which can bias the meaning of information.

Generally speaking, the mechanism of a firm's internationalization and learning is a very rich field for research and there will always be hints to follow and new suggestions to incorporate. With this article we tried to contribute to a better understanding of how learning takes place within networks and how that can be used to foster internationalization (Cumming, Sapienza, Siegel, \& Wright, 2009; Meyer, 2007; McDougall \& Oviatt, 2005; Simonin, 2004; Zahra, 2005).

\section{NOTES}

1. In 1993, Johanson and Vahlne had already presented three exceptions to this pattern.

2. In the sense used by Fricker (2006).

\section{REFERENCES}

Baum, J., Li, S., \& Usher, J. M. (2000). Making the next move: How experiential and vicarious learning shape the locations of chains acquisitions. Administrative Science Quarterly, 45, 766-801.

Bruneel, J., Yli-Renko, H., \& Clarysse, B. (2010). Learning from experience and learning from others: How congenital and interorganizational learning substitute for experiential learning in young firm internationalization. Strategic Entrepreneurship Journal, 4, 164182.

Christensen, P. R., \& Lindmark, L (1993). Location and internationalization of small firms. In L. Lundqvist and L. O. Persson (Eds.), Visions and strategies in European integration (pp.131-152). Berlin, Germany: Springer.

Cohen, W. M., \& Levinthal, D. A. (1990). Absorptive capacity: A new perspective on learning and innovation. Administrative Science Quarterly, 35, 128-152. 
Cumming, D., Sapienza, H. J., Siegel, D. S., \& Wright, M. (2009). International entrepreneurship: Managerial and policy implications. Strategic Entrepreneurship Journal, 3(4), 283-296.

Dunning, J. H. (2001). The eclectic (OLI) paradigm of international production: Past, present and future. International Journal of the Economics of Business, 8(2), 173-190.

Ford, D. (Ed.). (2002). Understanding business marketing and purchasing (3rd ed.). London, UK: Thomson Learning.

Ford, D., Gadde, L. E., \& Håkansson, H. (1988). Managing business relationships. Chichester, UK: Wiley.

Forsgren, M. (2000). Some critical notes on learning in the Uppsala internationalization process model (Working Paper 24). Uppsala, Sweden: Department of Business Studies, Uppsala University.

Forsgren, M. (2002). The concept of learning in the Uppsala internationalization process model: A critical review. International Business Review, 11, 257-277.

Fricker, E. (2006), Second-hand knowledge. Philosophy and Phenomenological Research, 73(3), 592-618.

Hadley, R. D., \& Wilson, H. I. M. (2003). The network model of internationalization and experiential knowledge. International Business Review, 12(6), 697-717.

Håkansson, H. (Ed.). (1982). International marketing and purchasing of industrial good: An interaction approach. Chichester, UK/New York, NY: Wiley.

Håkansson, H., \& Snehota, I. (1995). Developing relationships in business networks. London, UK: Routledge.

Håkansson, H., \& Waluszewski, A. (2002). Managing technological development: IKEA, the environment and technology (illustrated ed.). London, UK: Routledge.

Hallén, L., Johanson, J., \& Seyed-Mohamed, N. (1991). Interfirm adaptation in business relationships. Journal of Marketing, 55(2), 29.

Haunschild, P. R., \& Miner, A. S. (1997). Modes of interorganisational imitation: The effects of outcome salience and uncertainty. Administrative Science Quarterly, 44, 82-111.

Haveman, H. A. (1993). Follow the leader: Mimetic isomorphism and entry into new markets. Administrative Science Quarterly, 38, 593-627.

Holm, D. B., Eriksson, K., \& Johanson, J. (1999). Creating value through mutual commitment to business network relationships. Strategic Management Journal, 20(5), 467-486.

Huber, G. P. (1991). Organizational learning. The contributing processes and the literatures. Organization Science, 2(1), 88-115.

Johanson, J., \& Mattsson, L.-G. (1988). Internationalisation in industrial systems - a network approach. In N. Hood \& J.-E. Vahlne (Eds.), Strategies in global competition: Selected papers from the Prince Bertil Symposium at the Institute of International Business, Stockholm School of Economics (pp. 468-486). London, UK/New York, NY: Croom Helm.
Johanson, J., \& Vahlne J.-E. (1977). The internationalization process of the firm. A model of knowledge development and increasing foreign market commitments. Journal of International Business Studies, 8(1), 23-32.

Johanson, J., \& Vahlne, J.-E. (1990). The mechanism of internationalism. International Marketing Review, 7(4), $11-24$.

Johanson, J., \& Vahlne, J.-E. (1993). Management of internationalization. In L. Zan, S. Zambon, \& A. M. Pettigrew (Eds.), Perspectives on strategic change (pp. 43-71). London, UK: Kluwer Academic.

Johanson, J., \& Vahlne J.-E. (2003). Business relationship learning and commitment in the internationalisation process. Journal of International Entrepreneurship, $1,83-101$

Johanson, J., \& Vahlne J.-E. (2006). Commitment and opportunity development in the internationalization process: A note on the Uppsala internationalization process model. Management International Review, 46, $165-178$.

Johanson, J., \& Vahlne, J.-E. (2009). The Uppsala internationalization process model revisited: From liability of foreignness to liability of outsidership. Journal of International Business Studies, 40(9), 1411-1431.

Johanson, J., \& Wiedersheim-Paul, F. (1975). The internationalisation of the firm: Four Swedish case studies. Journal of Management Studies, 2(3), 305-322.

Kaufmann, F. (1994). Internationalization via cooperation: Strategies of SME. International Small Business Journal, 13(2), 27-33.

Kraatz, M. S. (1998). Learning by association? Interorganisational networks and adaptation to environmental changes. Academy of Management Journal, 41(6), 621-643.

Levitt, B., \& March, J. G. (1988). Organizational learning. Annual Review of Sociology, 14, 319-340.

McDougall, P. P., \& Oviatt, B. M. (2005). Defining international entrepreneurship and modeling the speed of internationalization. Entrepreneurship Theory and Practice, 29(5), 537-554.

Meneses, J. P. (2008). O nosso homem dos negócios na China [Our businessmen in China]. Ponto Final. Retrieved from www.marketaccess.pt/arq/fich/ PF1587_P7.pdf

Meyer, K. E. (2007). Contextualizing organizational learning: Lyles and Salk in the context of their research. Journal of International Business Studies, 38(1), 27-37.

O'Farrell, P. N., \& Hitchens, D. M. W. N. (1988). Alternative theories of small-firm growth: A critical review. Environment and Planning, 20(10), 1365-1383.

Rochester, C. (2005). The role of boards in small voluntary organizations. In C. Cornforth (Ed.), The governance of public and non-profit organisations: What do boarders do? (pp. 115-130). Oxon, UK: Routledge.

Sharma, D. D., \& Johanson, J. (1987). Technical consultancy in internationalisation. International Marketing Review, 4(Winter), 20-29. 
Simonin, B. L. (2004). An empirical investigation of the process of knowledge transfer in international strategic alliances. Journal of International Business Studies, 35(5), 407-428.

Welch, L. S., \& Welch D. E. (1996). The internationalization process and networks: A strategic management perspective. Journal of International Marketing, 4(3), $11-28$.

Whitelock, J. (2002). Theories of internationalisation and their impact on market entry. International Marketing Review, 19(4), 342-347.
World Trade Organization. (1994). Agreement on Textiles and Clothing (ATC). Retrieved from http://www. wto.org/english/docs_e/legal_e/16-tex.pdf

Yin, R. K. (2003). Case study research, design and methods (3rd ed.). London, UK: Sage.

Zaheer, S. (1995). Overcoming the liability of foreignness. Academy of Management Journal, 38(2), 341363.

Zahra, S. A. (2005). A theory of international new ventures: A decade of research. Journal of International Business Studies, 36, 20-28. 